\title{
KOMUNIKASI VERTIKAL DAN HORIZONTAL DALAM MEMBENTUK GAYA KEPEMIMPINAN BERBASIS KEARIFAN LOKAL: STUDI PADA BINUS UNIVERSITY
}

\author{
Lidia Wati Evelina; Mia Angeline
}

Marketing Communication Department, Faculty of Economic and Communication, BINUS University

Jln. K.H. Syahdan No. 9, Palmerah, Jakarta Barat 11480

lidiaevelina@yahoo.com; f.angeline@gmail.com

\begin{abstract}
Productivity of the company depends on a leader's attempt to control staff via two-way communication. Binus University as a university that relies on IT-based communication has several advantages: cost, distance, and time reduced. However there are also a few problems, such as unreadable nonverbal communication and lack of formality and respect between subordinates and superiors. This study aims to determine vertical and horizontal communication in Binus University which form leadership style based on company local wisdom so that the company may become an institution of higher education that counts. In addition, study aims to determine how corporate culture may establish the company local wisdom in Binus University. Study used descriptive-qualitative method by doing interview and observation to some key informants. Results show that Binus University implements vertical and horizontal flow of information for communication openly and equally within the university. Leadership in Binus always embeds culture that becomes values of Binusian which are composed of 5 points: trust in God, sense of belonging, sense of closing, benchmarking, and continuous improvement in every meeting between leaders and employees. Binus University has also implemented three components forming company local wisdom, namely transformational leadership, culture and corporate structure, and effective knowledge transfer method.
\end{abstract}

Keywords: vertical communication, horizontal communication, leadership style, local wisdom

\begin{abstract}
ABSTRAK
Produktivitas perusahaan bergantung pada upaya seorang pemimpin mengendalikan staf melalui komunikasi dua arah. Binus University sebagai universitas yang mengandalkan komunikasi berbasis IT memiliki beberapa kelebihan, yaitu berkurangnya biaya, jarak, dan waktu. Namun juga tidak sedikit masalah yang ada, seperti tidak terbacanya komunikasi nonverbal dan berkurangnya formalitas serta respek antara bawahan dengan atasan. Penelitian bertujuan untuk mengetahui komunikasi vertikal dan horizontal di Binus University yang membentuk gaya kepemimpinan berbasis kearifan lokal perusahaan sehingga dapat menjadi suatu lembaga pendidikan tinggi yang diperhitungkan. Selain itu penelitian bertujuan untuk mengetahui budaya perusahaan dapat membentuk kearifan lokal perusahaan di Binus University. Penelitian menggunakan metode kualitatif deskriptif dengan melakukan wawancara dan observasi beberapa informan kunci. Hasil penelitian memperlihatkan bahwa Binus University menerapkan aliran informasi vertikal dan horizontal untuk komunikasi di lingkungan universitas dengan terbuka dan setara. Kepemimpinan di Binus selalu menanamkan budaya yang menjadi nilai-nilai Binusian yang terdiri dari 5 poin yaitu trust in God, sense of belonging, sense of closing, benchmarking, dan continous improvement dalam setiap kesempatan pertemuan antara pimpinan dan karyawan. Binus University juga telah menerapkan tiga hal pembentuk kearifan lokal perusahaan, yaitu kepemimpinan transformasional, budaya dan struktur perusahaan, dan metode knowledge transfer yang efektif.
\end{abstract}

Kata kunci: komunikasi vertikal, komunikasi horizontal, gaya kepemimpinan, kearifan lokal 


\section{PENDAHULUAN}

Produktivitas perusahaan tergantung dari upaya seorang pemimpin mengendalikan stafnya melalui komunikasi dua arah. Kepemimpinan merupakan suatu elemen penting agar dapat menggali kreativitas staf dalam meningkatkan produktivitas. Pada lembaga perguruan tinggi produktivitas yang dimaksud adalah dapat mencetak lulusan yang langsung dapat bekerja di lapangan industri. Lembaga perguruan tinggi harus senantiasa mengikuti perkembangan dan kebutuhan industri agar kualitas lulusan tetap terjaga. Agar kepemimpinan ini dapat efektif, diperlukan komunikasi organisasi dan budaya organisasi yang kuat sehingga dapat terbentuk organizational wisdom yang dipakai seluruh karyawan. Untuk mendapatkan komunikasi organisasi yang efektif, perusahaan bergantung pada media komunikasi berbasis IT untuk mengurangi biaya, waktu, dan jarak.

Binus University saat ini adalah sebuah universitas swasta terkemuka di Jakarta yang menduduki peringkat empat perguruan tinggi swasta unggulan untuk kategori pengembangan sistem, mutu pelajaran, dan karya unggulan. Binus selama ini dikenal sebagai lembaga pendidikan tinggi pertama berbasis IT. Semua komunikasi organisasi dilakukan melalui teknologi komunikasi seperti email, SMS, BBM, website, Binusmaya, Facebook, dan Twiter. Sedangkan komunikasi tatap muka dilakukan ketika berkaitan dengan jadwal perkuliahan dan pengembangan dosen; informasi reguler disampaikan melalui media elektronik.

Sebagai universitas yang mengandalkan komunikasi berbasis IT, ada beberapa kelebihan yang bisa didapatkan, yaitu berkurangnya biaya, jarak, dan waktu. Namun juga tidak sedikit masalah yang ada jika perusahaan menggunakan media komunikasi yang berbasis IT, seperti tidak terbacanya komunikasi nonverbal dan berkurangnya formalitas serta respek antara bawahan dengan atasan. Selain itu juga ada masalah lain seperti pemilihan informasi, penyalahgunaan media komunikasi, hingga bocornya informasi rahasia perusahaan. Atas dasar pertimbangan ini, peneliti tertarik untuk meneliti mengenai komunikasi organisasi di Binus University yang berbasis IT dan menuangkan masalah penelitian sebagai berikut.

Masalah dalam penelitian ini adalah (1) bagaimana komunikasi vertikal dan horizontal di Binus University yang membentuk gaya kepemimpinan berbasis kearifan lokal perusahaan sehingga dapat menjadi suatu lembaga pendidikan tinggi yang diperhitungkan. Kemudian (2) bagaimana budaya perusahaan dapat membentuk kearifan lokal perusahaan di Binus University. Tujuan penelitian terkait dengan rumusan masalah yang akan diteliti adalah (1) mengetahui pola komunikasi vertikal dan horizontal di Binus University yang membentuk gaya kepemimpinan berbasis kearifan lokal sehingga menjadi lembaga pendidikan tinggi yang diperhitungkan, dan (2) mengetahui budaya perusahaan di Binus University yang dapat membentuk kearifan lokal perusahaan.

Hasil penelitian ini diharapkan (1) dapat menjadi referensi bagi peneliti lain yang juga meneliti topik mengenai gaya kepemimpinan atau kearifan lokal, (2) menjadi masukan bagi Binus University agar dapat memberdayakan bawahan melalui kegiatan-kegiatan nonformal, dan (3) memberikan masukan bagi seluruh pembaca mengenai bahasan gaya kepemimpinan dan kearifan lokal khususnya di Binus University.

\section{Tinjauan Pustaka}

\section{Iklim Komunikasi, Budaya Perusahaan, dan Gaya Kepemimpinan Berbasis Kearifan Lokal}

Iklim organisasi di dalam perusahaan merupakan suatu istilah yang dipakai untuk menggambarkan keadaan fisik dan memberi informasi mengenai struktur dan arti dari situasi. 
Sedangkan iklim komunikasi dapat diterjemahkan sebagai gabungan persepsi-persepsi dan merupakan suatu evaluasi secara makro mengenai peristiwa komunikasi, perilaku manusia dan respons karyawan. Jadi iklim organisasi dapat memengaruhi iklim komunikasi. Iklim organisasi adalah cara anggota bertingkah laku dan berkomunikasi.

Iklim komunikasi di dalam perusahaan mencakup harapan-harapan, konflik antarpersonal, dan kesempatan bagi pertumbuhan dalam organisasi tersebut. Iklim komunikasi berbeda dengan iklim organisasi. Iklim komunikasi meliputi persepsi-persepsi mengenai pesan dan peristiwa yang berhubungan dengan pesan yang terjadi dalam organisasi. Persepsi mengenai suatu organisasi pada hari tertentu dapat memberi gambaran jelas mengenai iklim komunikasi organisasi tersebut dalam jangka waktu yang lebih panjang (Pace dan Faules, 2005). Muhamad (2005) menambahkan di dalam iklim komunikasi yang penuh persaudaraan mendorong para anggota organisasi berkomunikasi secara terbuka, relaks, ramah tamah dengan anggota lainnya. Sebaliknya, iklim negarif menjadikan anggota tidak berani berkomunikasi secara terbuka dan penuh persaudaraan (Muhamad, 2005).

Dapat disimpulkan bahwa iklim dalam organisasi yang ada pada perusahaan merupakan akibat dari sistem komunikasi dan peristiwa di dalam perusahaan yang dipersepsikan oleh masing-masing karyawan dalam jangka waktu panjang. Di dalam perusahaan perlu mengkondisikan iklim komunikasi yang penuh persaudaraan mendorong para anggota organisasi berkomunikasi secara terbuka, rileks, ramah tamah dengan anggota lainnya.

Gaya kepemimpinan disuatu perusahaan terkait dengan iklim komunikasi di perusahaan tersebut. Gaya kepemimpinan yang lebih sesuai dengan kondisi saat ini adalah gaya pengajak serta seperti dikemukan oleh Rensist Likert dalam Masmuh (2010). Gaya ini amat sportif dengan tujuan agar organisasi berjalan dengan baik melalui partisipasi pegawai. Informasi berjalan ke segala arah pengendalian dijalankan di setiap tingkatan. Orang berkomunikasi dengan bebas, terbuka, dan berterus terang, hampir tanpa rasa takut terhadap hukuman. Tingkat peran serta pegawai yang paling tinggi, menghasilkan tingkat produktivitas yang paling tinggi pula.

Tannenbaum dan Schmidt dalam Masmuh (2010) berasumsi bahwa pemimpin yang paling efektif adalah mereka yang mempunyai gaya pemimpin yang konsisten, sesuai dengan tuntutan situasi. Jika instruksi diperlukan, pemimpin memberi instruksi. Jika diperlukan keikutsertaan dalam mengambil keputusan, pemimpin melonggarkan pengawasan dan memberikan tim berperan dalam pengambilan keputusan.

Suatu perusahaan yang sudah bertahun-tahun didirikan tentunya memiliki budaya perusahaan yang khas yang membedakan dengan perusahaan lainnya. Budaya itu dapat berasal dari pemilik awal perusahaan dan dapat juga dari pucuk pimpinan atau level direksi. Pada masa sekarang budaya juga dapat tercipta dari kelompok karyawan yang berpengaruh. Budaya perusahaan menurut Kasali (2008) adalah satu set nilai dan merupakan kepercayaan yang menuntun kepada suatu hal. Selain itu juga budaya perusahaan adalah suatu pengertian dan menjadi cara berpikir yang dipertemukan oleh para anggota organisasi dan diterima oleh anggota baru seutuhnya. Sebenarnya tujuan dari budaya perusahaan tersebut adalah untuk melengkapi para anggota dengan identitas organisasi dan menimbulkan komitmen terhadap nilai-nilai yang dianut oleh organisasi (Kasali, 2008).

Sebuah perusahaan harus dipandang sebagai suatu kesatuan sosial dan budaya dari suatu perusahaan. Organisasi dalam suatu perusahaan beserta seluruh pekerjanya harus memiliki seperangkat nilai dan tujuan yang sama. Itulah yang sering terdengar bahwa seluruh anggota atau karyawan dalam perusahaan harus memiliki sense of belonging dan menikmati pertumbuhan dan hasil dari kerja mereka. Menurut Masmuh (2010), budaya perusahaan itu harus terkait dengan moral dan produktivitas pekerja dan itu terintergrasi. Dengan demikian, budaya dari suatu perusahaan adalah hasil dari penerapan nilai-nilai yang harus dipahami bersama oleh seluruh karyawan dan menjadi 
identitas dari perusahaan tersebut. Untuk mencapai tujuan bersama, budaya perusahaan harus merupakan paduan dari moral dan produktivitas dari seluruh karyawan di perusahaan tersebut.

Budaya perusahaan juga memiliki nilai kearifan lokal. Pengertian kearifan lokal berasal dari dua kata yaitu kearifan (wisdom) dan lokal (local). Sehingga kearifan lokal dapat dipahami sebagai gagasan, nilai, atau pandangan lokal yang bersifat bijaksana, penuh kearifan, bernilai baik, tertanam, dan diikuti oleh anggota masyarakat. Sedangkan menurut Bierly, Kessler, dan Christensen (2000) kearifan berarti kemampuan untuk menggunakan pengetahuan (knowledge) untuk meraih goals yang diinginkan.

Sementara pengertian kearifan lokal yang dipakai dalam penelitian mengacu pada istilah organizational wisdom. Artinya, strategi atau kearifan lokal perusahaan yang dikembangkan dikomunikasikan ke seluruh karyawan, dan dipakai dalam kompetisi pasar. Tiga hal penting yang membentuk kearifan lokal perusahaan menurut Bierly, Kessler, dan Christensen (2000) adalah kepemimpinan transformasional, budaya dan struktur perusahaan, dan mekanisme knowledge transfer yang efektif.

\section{Aliran Informasi dalam Komunikasi Organisasi}

Pola komunikasi yang ada dalam organisasi dapat dibagi menjadi 2 bagian besar, yaitu komunikasi vertikal (ke atas dan ke bawah) dan komunikasi horizontal (setara). Di kedua jenis komunikasi ke atas maupun ke bawah, manajemen mengendalikan sistem komunikasi. Para manajer memiliki waktu, keahlian, dan fasilitas untuk memperbaiki komunikasi yang ada di organisasi.

Tentunya, logis saja untuk menempatkan tanggung jawab atas terjadinya sistem komunikasi yang efektif pada pundak manajemen. Ini tidak lalu berarti bahwa para karyawan tidak perlu bertanggung jawab atas hal tersebut. Komunikasi yang efektif adalah proses dua arah. Bagaimanapun juga, manajemen menanggung tanggung jawab yang lebih besar dalam membentuk dan mempertahankan sistem komunikasi yang efektif dan efisien.

\section{Komunikasi Vertikal}

Di dalam komunikasi terdapat arus informasi. Menurut De Vito (2011), arus informasi dalam komunikasi organisasi terdiri dari komunikasi ke atas dan komunikasi ke bawah (sering disebut vertikal) dan komunikasi lateral, selain informasi samar (kabar burung) dan juga pada sebab dan akibat adanya kepadatan informasi. Komunikasi ke atas merupakan pesan yang dikirim dari tingkat hierarki yang lebih rendah ke tingkat yang lebih tinggi; misalnya, para pelaksana ke manajer, atau dari para dosen ke dekan fakultas. Jenis komunikasi ini biasanya mencakup (1) kegiatan yang berkaitan dengan pekerjaan, hal yang sedang terjadi di pekerjaan, seberapa jauh pencapaian, hal yang masih harus dilakukan, dan masalah lain yang serupa; (2) masalah yang berkaitan dengan pekerjaan dan pertanyaan yang belum terjawab; (3) berbagai gagasan untuk perubahan dan saran-saran perbaikan; dan (4) perasaan yang berkaitan dengan pekerjaaan mengenai organisasi, pekerjaan itu sendiri, pekerja lainnya, dan masalah lain yang serupa. (De Vito, 2011)

Senada dengan pendapat yang dikemukan De Vito, Wayne (dalam Pace dan Faules, 2005) juga mengungkapkan bahwa komunikasi ke atas dalam sebuah organisasi berarti bahwa informasi mengalir dari tingkat yang lebih rendah (bawahan) ke tingkat yang lebih tinggi (penyelia). Semua pegawai dalam sebuah organisasi, kecuali mungkin mereka yang menduduki posisi puncak, mungkin berkomunikasi ke atas. Maksudnya, setiap bawahan dapat mempunyai alasan yang baik atau meminta informasi dari atau memberi informasi kepada seseorang yang memiliki otoritas lebih tinggi daripada karyawan tersebut. Bentuknya dapat berupa suatu permohonan dan komentar yang diarahkan kepada 
individu yang memiliki otoritas lebih besar, lebih tinggi, atau lebih luas merupakan esensi komunikasi ke atas.

Berdasarkan hal tersebut, dapat disimpulkan bahwa komunikasi ke atas bersifat permohonan dan komentar serta informasi mengenai pekerjaan yang mereka lakukan. Komunikasi ke atas itu dapat berupa informasi kepada atasan mengenai pekerjaan yang mereka lakukan dari mulai persoalan yang mereka hadapi dan juga usulan berupa gagasan atau ide untuk kemudahan mereka dalam melaksanakan pekerjaan. Selain itu juga keluhan mengenai pekerjaan itu sendiri dan hambatan yang mereka hadapi terkait dengan pekerjaan.

Sementara itu, komunikasi ke bawah merupakan pesan yang dikirim dari tingkat hierarki yang lebih tinggi ke tingkat yang lebih rendah. Sebagai contoh, pesan yang dikirim dari dekan fakultas kepada para dosen adalah komunikasi ke bawah. Perintah sering kali merupakan contoh jelas untuk komunikasi ke bawah: "Ketik surat ini rangkap dua," "Isi form individual plan untuk masing-masing dosen," dan sebagainya. Pemberian perintah ini biasanya bersamaan dengan penjelasan prosedur, tujuan, dan sebagainya. Para pimpinan juga bertanggung jawab dalam memberi penilaian kepada karyawannya dan memotivasi mereka. Semuanya mengatasnamakan produktivitas dan demi kebaikan organisasi secara keseluruhan (De Vito, 2011).

Ada lima jenis informasi yang biasa dikomunikasi dari atasan kepada bawahan. Katz dan Kahn (dalam Pace \& Faules, 2005) mengemukakan tentang (1) informasi mengenai bagaimana melakukan pekerjaan, (2) informasi mengenai dasar pemikiran untuk melakukan pekerjaan, (3) informasi mengenai kebijakan dan praktik-praktik dalam organisasi, (4) informasi mengenai kinerja pegawai dan (5) informasi untuk mengembangkan rasa memiliki tugas (sense of mission). Jika disimpulkan dari dua pendapat tersebut, komunikasi ke bawah dalam organisasi berfungsi sebagai perintah dari jenjang posisi jabatan yang lebih tinggi ke jenjang posisi jabatan yang lebih rendah untuk melaksanakan suatu tugas operasional.

\section{Penyebaran Informasi}

Guetzkow dalam Pace dan Faules (2005) mengatakan bahwa aliran informasi di dalam suatu organisasi dapat terjadi melalui tiga cara, yaitu: serentak, berurutan, atau kombinasi dari dua cara itu. Pace dan Faules (2005) menjelaskan bahwa penyebaran pesan secara serentak dari orang ke orang lainnya dalam organisasi secara diadik melibatkan sumber pesan dan penerima. Penerima dalam hal ini menginterpretasikan pesan sebagai tujuan akhir. Pesan dapat berupa memo melalui email yang dikirim kepada sejumlah orang dalam organisasi. Memo itu dapat berisi mengenai perubahan jadwal atau penjelasan mengenai prosedur baru dalam organisasi. Bentuk informasi dapat tertulis melalui media internal, papan pengumuman, majalah, melalui online dan melalui media tatap muka/secara lisan di hadapan anggota organisasi yang dituju. Semua informasi yang diterima oleh anggota organisasi dalam waktu yang bersamaan itu yang disebut dengan penyebaran pesan secara serentak.

Berikutnya, penyebaran informasi dapat dilakukan dengan penyebaran secara berurutan yang biasa dipakai dalam organisasi berskala besar. Menurut Pace dan Faules (2005), penyebaran informasi secara berurutan meliputi perluasan bentuk penyebaran diadik. Jadi pesan dari A kepada B kemudian kepada C lalu diteruskan kepada D, dilanjutkan kepada E. Setiap individu kecuali orang pertama (sumber pesan), menginterpretasikan pesan yang diterimanya dan kemudian meneruskan hasil interpretasinya kepada orang setelah dia dalam suatu rangkaian.

Penyebaran informasi secara berurut ini mempunyai pola sebagai ciri terpentingnya. Penyebaran informasi seperti ini berlangsung pada waktu yang tidak beraturan. Jadi informasi yang diterima bisa saja di tempat dan waktu yang berlainan. Masalah yang dapat timbul adalah koordinasi karena keterlambatan dalam penyebaran informasi. Hal tersebut dapat menyebabkan informasi sulit digunakan untuk membuat keputusan karena ada anggota organisasi yang belum menerima informasi. 
Demikian pula, ketika anggota yang harus mendapatkan informasi dalam jumlah yang banyak. Dampak lainnya, kebenaran dan kecermatan informasi dapat saja tidak sebagaimana adanya diakibatkan dari interpretasi dan reproduksi pesan yang berlangsung dalam penyampaian pesan berurutan tersebut.

\section{METODE}

Pendekatan yang digunakan dalam penelitian ini adalah pendekata post-positivistic. Postpositivistic adalah aliran yang ingin memperbaiki kelemahan pada positivisme. Kesamaan antara kedua aliran ini adalah realitas memang nyata sesuai hukum alam, tetapi post-positivistic berpendapat manusia tidak mungkin mendapatkan kebenaran dari realitas jika peneliti membuat jarak dengan realitas atau tidak terlibat langsung dengan realitas. Hubungan antara peneliti dengan realitas harus bersifat interaktif. Untuk itu perlu digunakan prinsip triangulasi, yaitu penggunaan bermacam metode, sumber data, dan lainnya. Jenis penelitian yang digunakan adalah penelitian kualitatif deskriptif, yang fokusnya adalah penggambaran secara menyeluruh tentang bentuk, fungsi, dan makna ungkapan. Sesuai dengan pendapat Bogdan dan Taylor (Moleong, 2002), metode kualitatif sebagai prosedur penelitian yang menghasilkan data deskriptif berupa kata-kata tertulis atau lisan dari orang-orang dan perilaku yang dapat diamati.

Untuk mendapatkan hasil, penelitian mengggunakan teknik pengumpulan data primer dan sekunder. Pengumpulan data primer melalui wawancara semistruktur. Pewawancara menyiapkan daftar pertanyaan tertulis dan memungkinkan untuk menanyakan pertanyaan lainnya secara bebas sesuai situasi dan kondisi, terkait permasalahan sehingga mendapatkan data lengkap. Wawancara dilakukan dengan terarah/wawancara bebas terpimpin dengan tetap pada jalur pokok permasalahan dan sudah dipersiapkan terlebih dahulu (Kriyantono, 2006). Selain wawancara, observasi juga dilakukan untuk mendapatkan data primer. Kegiatan observasi adalah kegiatan yang menggunakan pancaindra. Observasi diartikan sebagai kegiatan mengamati objek secara langsung, mencakup interaksi (perilaku) dan percakapan yang terjadi di antara subjek yang diteliti (Kriyantono, 2006). Daymon dan Holloway (2008) menambahkan bahwa kegiatan observasi adalah mengidentifikasi tindakan sadar dan tindakan yang terjadi secara otomatis. Kemudian dijelaskan lebih jauh bahwa observasi digunakan untuk menyajikan teknik yang membedakan antara yang dikatakan dengan yang benar-benar mereka lakukan (Daymon \& Holloway, 2008).

Sedangkan untuk mendapatkan data sekunder, studi pustaka dilakukan dengan mencari data dokumen resmi, yaitu data dari website dan data lain berupa brosur kegiatan. Dokumen resmi terbagi atas dokumen internal dan eksternal. Dokumen internal berupa memo, pengumuman, instruksi, laporan rapat, konvensi, dan kebiasaan lainnya yang berlangsung di suatu lembaga. Sedangkan dokumen eksternal adalah informasi yang dikeluarkan suatu lembaga seperti majalah, buletin, berita yang disiarkan media massa, pengumuman, dan pemberitahuan (Bungin, 2008).

Setelah data terkumpul, data akan dianalisis dengan menggunakan tahapan analisis data dari Miles dan Huberman, terdiri dari tiga tahap. Tahap pertama adalah tahap reduksi data; tahap kedua penyajian data; dan tahap ketiga penarikan simpulan dan verifikasi data. Keabsahan dari data tersebut menggunakan uraian rinci yaitu suatu temuan dapat diterima ketika dijelaskan terperinci dan gamblang, logis serta rasional (Bungin, 2008). Metode triangulasi teori dan sumber data dilakukan untuk menguji keabsahan data. 


\section{HASIL DAN PEMBAHASAN}

\section{Komunikasi Vertikal dan Horizontal di Binus University}

Kebijakan mutu Binus University berkomitmen untuk menyediakan pendidikan kelas dunia dengan pengalaman belajar internasional yang memberikan kontribusi positif bagi masyarakat global. Dengan visi dari Binus adalah world class university dan lulusan Binus diterima di pasar global dan lingkungan melalui tingkat tertinggi pengajaran pendidikan keunggulan meliputi pembelajaran dan penelitian terapan. Sedangkan misi Binus University adalah memberikan kontribusi kepada masyarakat global melalui penyediaan pendidikan kelas dunia oleh pengakuan dan penghargaan yang paling kreatif dan nilai tambah bakat serta meningkatkan kualitas hidup masyarakat Indonesia dan masyarakat internasional. Untuk mencapai visi dan misi tersebut, sejak awal Binus berdiri para pendirinya menanamkan nilai sebagai berikut: ulet, bertindak fokus penuh gairah, komitmen dalam menentukan arah tujuan bersama, kebebasan untuk inovasi, integritas dengan semangat kreatif, dan pandangan jauh ke depan untuk mengenali dan mengambil tindakan pada kesempatan masa depan.

Menurut Wakil Rektor I bidang akademik, Iman H. Kartowisastro, value yg ada di Binus tidak membedakan jabatan, suku, dan latar belakang. Ia menegaskan bahwa nilai Binus sudah dimulai pendiri Binus yang tidak membedakan pangkat dan jabatan dan lebih mengutamakan kesetaraan dalam bentuk apa pun dan bersifat terbuka terhadap berbagai persoalan yang ada. Kalaupun ada hambatan, itu bukan merupakan masalah yang berarti, hanya mungkin lebih banyak waktu tersita dan masingmasing harus bersikap lebih bijaksana. Nilai kesetaraan itu diaplikasikan mulai dari jabatan terendah hingga pucuk pimpinan. Sikap terbuka ini mencerminkan seolah-olah hierarki tidak ada.

Media komunikasi yang dipakai untuk komunikasi secara vertikal hampir semuanya berbasis IT; media komunikasi yang utama adalah web Binus (Binusmaya) dan email. Seluruh Binusian wajib secara berkala melihat web Binus karena semua informasi tentang kegiatan disampaikan di web tersebut. Contoh persyaratan untuk mengikuti wisuda dapat diakses di Binusmaya dengan tingkat kesalahan kurang dari 1 persen. Seolah pemanfaatan multimedia mengasumsikan Binusian sebagai robot, namun seiring berjalannya waktu, hal tersebut akan menjadi kebiasaan. Media komunikasi berbasis IT ini juga menjadi sarana komunikasi horizontal antarrekan kerja. Sebagai contoh, forum diskusi di web Binus dan milis disediakan funtuk memudahkan komunikasi.

Melalui media komunikasi berbasis IT keuntungan yang diperoleh selain efisiensi waktu adalah hilangnya jarak antarindividu, tidak ada batasan jabatan atau usia sehingga makin menunjang value kesetaraan yang dijunjung Binus. Value ini ditekankan kepada setiap bawahan tidak hanya melalui sosialisasi tetapi juga dari contoh perbuatan yang dilakukan oleh rektor, dengan harapan dapat dicontoh oleh jajaran menengah dan staf Binus. Misalnya ketika induksi dosen dan karyawan baru, Pak Rektor atau Wakil Rektor selalu hadir dan memberikan nomor kontak pribadi yang dapat dihubungi tanpa harus melewati birokrasi. Keterbukaan ini juga mendukung komunikasi dari bawahan ke atasan, sehingga masukan dari bawahan dapat tersampaikan ke pimpinan tanpa melewati jenjang yang bertahap. Penekanan nilai keterbukaan dan kesetaraan melalui sosialisasi dan tindakan pimpinan ini efektif dalam membentuk gaya kepemimpinan di dalam Binus University, di jajaran middle management dan seluruh jurusan mengaplikasikan open door policy dibantu dengan media komunikasi berbasis IT.

Aplikasi komunikasi organisasi di Binus University sudah sesuai dengan teori mengenai iklim komunikasi dari Wayne dan Muhammad, yang mengatakan iklim komunikasi yang penuh persaudaraan akan membuat anggota organisasi bersikap terbuka. Keterbukaan ini terus dibina oleh Binus melalui event, termasuk rapat dosen setiap awal semester yang mendorong keakraban antardosen. Binus University juga menerapkan penyebaran komunikasi gabungan antara serentak dan 
berurutan sesuai dengan teori dari Guetzkow dalam Wayne, penyebaran informasi serentak kepada seluruh Binusian jika terkait dengan pengumuman acara atau pengumuman keberhasilan universitas, sedangkan penyebaran informasi berurutan terkait dengan implementasi kebijakan per jurusan.

Binus University juga telah mengaplikasikan komunikasi vertikal sesuai dengan teori dari Wayne (Pace \& Faules, 2005) dan DeVito (2011) yang mengatakan komunikasi ke bawah itu salah satunya terdiri dari Informasi mengenai cara melakukan pekerjaan. Karena iklim komunikasi Binus yang berbasis IT, seluruh Binusian diharapkan tanggap IT, dan harus mengisi sejumlah formulir yang berkaitan dengan tugas mereka. Untuk memenuhi hal ini, Binus secara konsisten mengadakan pelatihan bagi para karyawan untuk meningkatkan kompetensi mereka dan membantu mereka dalam melakukan pekerjaan.

Dilihat dari gaya kepemimpinan yang dipraktikan mulai dari pucuk pimpinan hingga middle management, Binus University termasuk dalam gaya mengajak sesuai dengan yang dikatakan oleh Rensist Likert dalam Masmuh (2010). Seperti pada contoh yang telah dikemukakan, mulai dari rektor Binus menerapkan gaya mengajak melalui contoh perbuatan yang dapat dilihat oleh para bawahannya. Komunikasi terbuka sudah sejak awal diterapkan kepada karyawan yang baru bergabung. Rektor beserta pimpinan lainnya memberikan akses nomor handphone untuk menyampaikan informasi yang diperlukan. Semua binusian diberi hak untuk menyampaikan masukan sebelum menjadi keputusan bersama seperti di dalam rapat kerja.

\section{Budaya Perusahaan dalam Membentuk Kearifan Lokal Binus University}

Lidya Kosasih dari unit Corporate Learning Directorate yang sudah bekerja selama 10 (sepuluh) tahun sejak masih menjadi mahasiswi semester 6 (enam) menjelaskan bahwa setiap Binusian yang ingin bergabung menjadi dosen maupun karyawan harus mengikuti proses induksi. Terdapat dua jenis induksi di Binus, yaitu induksi dosen yang lebih bersifat akademis dan informasi penggunaan media komunikasi di Binus seperti Binusmaya, email Binus, Facebook, Twitter Binus dan media komunikasi lainnya. Yang kedua adalah induksi karyawan yang bertujuan untuk mensosialisasikan Binus culture yang terdiri dari 5 poin. Pertama, trust in God, contohnya setiap kegiatan selalu diawali dan diakhiri doa. Kedua, sense of belonging, Binusian merawat setiap fasilitas Binus seperti miliknya sendiri contoh paket alat mengajar yg terdiri dari mic, remote LCD, dan spidol. Ketiga, sense of closing, selalu ada penilaian evaluasi dr pekerjaan yg dijalankan, seperti IKADQ dosen hasil dari evaluasi mahasiswa atau Indeks Kepuasan mahasiswa dan KPI karyawan. Keempat, benchmarking, menjadi standar bagi dunia pendidikan tinggi. Kelima, continous improvement, selalu mengembangkan diri, contoh mengajak industri untuk ikut proses pembelajaran dengan nama global learning system.

Selain itu Binus memiliki 4 nilai utama. Pertama, farsight, melihat jauh ke depan. Kedua, diversity, keberagaman. Ketiga, tenacious focus dan keempat freedom to innovate. Semuanya yang disebutkan akan selalu diingatkan setiap minggu dalam rapat dengan pimpinan dan ketika membuat proyek, termasuk juga melalui kegiatan pemberdayaan karyawan contoh rapat kerja akademik sampai dengan acara keakraban melalui family gathering dan lecturer gathering. Semua yang tercakup dalam Tridarma Perguruan Tinggi selalu bernapaskan budaya Binus sampai dengan pengabdian masyarakat melalui Teach For Indonesia (TFI). Binus membentuk unit-unit pendukung kegiatan akademis, misal Corporate Learning Directorate, Student Affairs and Community Development, Lecturer Research Center, Academic Development, Operation and Resource Management, Research and Institutional Development, Quality Management Center, Information Technology Directorate. Semua unit itu menjadi tim kerja yang terkoordinasi dengan baik.

Dengan demikian masing-masing unit di Binus saling bersinergi membentuk budaya lokal yang berbasis IT. Para pemimpin Binus dalam berkomunikasi memiliki kedudukan yang setara, artinya komunikasi dapat saja dilakukan langsung dan terbuka tidak perlu melalui birokrasi yang 
rumit. Informasi yang berupa masukan dapat saja dikemukakan secara formal dan nonformal. Komunikasi nonformal dapat melalui sosial media, email, Facebook, Twitter, BBM, SMS, Whatsapp dan media komunikasi lainnya.

Sesuai dengan teori ada tiga hal penting yang membentuk kearifan lokal perusahaan menurut Bierly, Kessler, dan Christensen (2000), yaitu: kepemimpinan transformasional, budaya dan struktur perusahaan, dan mekanisme knowledge transfer yang efektif. Binus telah mengaplikasikan tipe kepemimpinan transformasional, yang berarti pimpinan di Binus dapat mendorong awareness dan penerimaan visi dan misi Binus ke seluruh karyawan, sehingga semua karyawan Binus bekerja untuk mencapai visi dan misi tersebut. Masih menurut Bierly, Kessler, dan Christensen (2000) bahwa kepemimpinan transformasional bekerja dengan baik jika perusahaan memprioritaskan spiritualitas, hal ini sejalan dengan budaya Binus yang paling pertama, yaitu trust in God.

Hal yang membentuk kearifan lokal perusahaan yang kedua adalah budaya dan struktur perusahaan. Menurut Barney dikutip dalam Bierly, Kessler, dan Christensen (2000) budaya perusahaan yang akan mendatangkan keuntungan bagi perusahaan adalah budaya yang mengedepankan kebutuhan karyawan, konsumen, komunitas, dan publik utama lainnya bagi perusahaan tersebut. Binus dengan komunikasi organisasi yang berbasis IT dan dapat menghilangkan hambatan birokrasi dan hierarki, maka telah mengedepankan kebutuhan dan suara karyawan. Melalui Teach For Indonesia (TFI) Binus telah mengedepankan komunitas, serta melalui unit-unit pendukung akademis, seperti yang telah disebutkan, juga telah mengedepankan konsumen atau dalam hal ini mahasiswa dan para orangtua.

Hal terakhir yang membentuk kearifan lokal perusahaan adalah metode knowledge transfer yang efektif. Budaya dan nilai-nilai perusahaan harus disosialisasikan, dikembangkan, dan secara rutin diingatkan kembali ke seluruh karyawan perusahaan. Knowledge transfer ini telah dilakukan Binus melalui program induksi karyawan dan dosen, rapat mingguan, rapat kerja akademis, rapat per semester, lecturer gathering, family gathering, dan program-program serta acara lainnya. Knowledge transfer juga dilakukan, selain melalui sosialisasi juga melalui tindakan nyata dari para pimpinan yang diharapkan dicontoh oleh para karyawan lainnya. Selain itu Binus tidak hanya melakukan knowledge transfer ke publik internal saja, tetapi juga mengembangkan knowledge dengan mengundang publik eksternal yaitu dari industri pekerjaan. Hal itu dilakukan dengan cara membuka web Binusmaya kepada industri agar mereka dapat mengetahui materi perkuliahan dan memberi masukan baik kepada dosen maupun mahasiswa secara langsung. Metode ini diberi nama Global Learning System. Berdasarkan hal tersebut, Binus telah melakukan tiga hal pembentuk kearifan lokal perusahaan dan selalu mengembangkan nilai-nilai dan budaya perusahaan agar tercapainya tujuan bersama.

\section{SIMPULAN}

Berdasarkan hasil dan pembahasan, penelitian menyimpulkan sebagai berikut. Binus University menerapkan aliran informasi vertikal dan horizontal untuk komunikasi di lingkungan universitas dengan terbuka dan setara. Artinya, di Binus dalam hal berkomunikasi tidak memandang atasan dan bawahan selama informasi tersebut diperlukan untuk kegiatan universitas. Gaya kepemimpinan di Binus University melakukan komunikasi vertikal dan horizontal dengan menggunakan bantuan teknologi komunikasi dibandingkan dengan tatap muka. Kepemimpinan di Binus selalu menanamkan budaya yang menjadi nilai-nilai Binusian yang terdiri dari 5 poin, yaitu trust in God, sense of belonging, sense of closing, benchmarking, continous improvement dalam setiap kesempatan pertemuan antara pimpinan dan karyawan. Kemudian, Binus University juga telah menerapkan tiga hal pembentuk kearifan lokal perusahaan. Pertama, kepemimpinan transformasional terlihat dari budaya spiritualitas yang ada pada nilai Binus trust in God. Kedua, budaya dan struktur 
perusahaan, dengan menggunakan media komunikasi berbasis IT, Binus menghilangkan batasan birokrasi dan hierarki; selain itu melalui program Teach For Indonesia dan unit-unit pendukung akademis yang seluruhnya dibangun untuk memenuhi kebutuhan publik-publik primer Binus University. Ketiga, metode knowledge transfer yang efektif dilakukan Binus melalui program induksi, rapat, sosialisasi, dan program Global Learning System.

Sementara saran yang dapat diberikan melalui penelitian ini adalah sebagai berikut. Pertama, Binus membuat mekanisme untuk penyampaian pesan yang efektif dalam hubungan komunikasi vertikal. Jika ada saran atau masukan ke atas, diharapkan menggunakan standar formulir resmi dengan tujuan untuk memudahkan pembaca. Kedua, dalam komunikasi vertikal, diperlukan peran pemimpin dalam menanamkan persepsi yang sama dari masing-masing karyawan di Binus University dan memerhatikan karakter dan kebutuhan staf. Seorang pemimpin perlu melakukan komunikasi yang tidak hanya dapat mengendalikan atau mengarahkan dan menjelaskan kepada atau memberi instruksi kepada orang lain, tetapi juga perlu memberikan tantangan atau rangsangan kepada orang lain atau melibatkan atau memberdayakan orang lain. Pemimpin, setelah itu, memberi ganjaran atau memperkuat motivasi orang tersebut. Pemimpin juga selalu melakukan koordinasi dan berdiskusi dengan staf untuk mengetahui hambatan yang terjadi secara dini sehingga bisa mengatasi berbagai hal yang terjadi. Ketiga, dalam Komunikasi horizontal, diperlukan adanya pemahaman antara masingmasing karyawan di Binus dengan memperbanyak forum kegiatan nonformal yang bersifat relaks (santai) untuk menjalin keakraban seperti diskusi ringan-selama ini hanya gathering dan rekreasi karyawan.

\section{DAFTAR PUSTAKA}

Bierly, E. P., Kessler, H. E., \& Christensen, W. E. (2000). Organizational Learning, Knowledge and Wisdom. Journal of Organizational Change Management, 595.

Bungin, B. (2008). Metode Penelitian Kualitatif. Komunikasi, Ekonomi. Kebijakan Publik dan Ilmu Sosial lainnya. Jakarta: Kencana Prenada.

Daymon, C., \& Holloway, I. (2008). Alih Bahasa: Cahya Wiratama. Riset Kualitatif dalam Public Relations dan Marketing Communications. Cetakan pertama. Yogyakarta: Bentang Pustaka.

DeVito, J. (2011). Human Communication. New York: Pearson Education.

Kasali, R. (2008). Manajemen Public Relations. Konsep dan Apilikasinya di Indonesia. Cetakan ketujuh. Jakarta: Pustaka Utama Grafiti.

Kriyantono, R. (2006). Teknik Praktis Riset Komunikasi. Jakarta: Kencana Prenada Media Group.

Masmuh, A. (2010). Komunikasi Organisasi dalam Perspektif Teori dan Praktik. Malang: UMM Press.

Moleong, L. J., Surjaman, T. (2002). Metodologi Penelitian Kualitatif. Jakarta: Remaja Rosdakarya.

Muhamad, A. (2005). Komunikasi Organisasi. Jakarta: Bumi Aksara.

Pace, R. W., \& Faules, D. F. (2005). Komunikasi Organisasi. Strategi Meningkatkan Kinerja Perusahaan. Alih bahasa: Deddy Mulyana. Bandung: Remaja Rosdakarya.

Rowley, J. (2006). What do we need to know about wisdom? Management Decision, 1246-1257. 